\title{
Properties and Fermentation Activity of Industrial Yeasts Saccharomyces cerevisiae, S. uvarum, Candida utilis and Kluyveromyces marxianus Exposed to AFB, OTA and ZEA
}

\section{Željko Jakopović ${ }^{*}$, Karla Hanousek Čiča², Jasna Mrvčić , Irina Pucićs , Iva Čanak', Jadranka Frece', Jelka Pleadin ${ }^{4}$, Damir Stanzer ${ }^{2}$, Slaven Zjalićs and Ksenija Markov ${ }^{1}$}

'Department of Biochemical Engineering, Faculty of Food Technology and Biotechnology, University of Zagreb, Pierottijeva 6, HR-10000 Zagreb, Croatia 2Department of Food Engineering, Faculty of Food Technology and Biotechnology, University of Zagreb, Pierottijeva 6, HR-10000 Zagreb, Croatia

${ }^{3}$ Department of Materials Chemistry, Ruđer Bošković Institute, Bijenička cesta 54, HR-10000 Zagreb, Croatia ${ }^{4}$ Laboratory for Analytical Chemistry, Croatian Veterinary Institute, Savska cesta 143, HR-10000 Zagreb, Croatia 5Department of Ecology, Agronomy and Aquaculture, University of Zadar, M. Pavlinovića 1, HR-23000 Zadar, Croatia

Received: 27 October 2017 Accepted: 17 January 2018

\section{SUMMARY}

In this paper the effect of aflatoxin $\mathrm{B}_{1}$, ochratoxin $\mathrm{A}$ and zearalenon on morphology, growth parameters and metabolic activity of yeasts Saccharomyces cerevisiae, Saccharomyces uvarum, Candida utilis and Kluyveromyces marxianus was determined. The results showed that the three mycotoxins affected the morphology of all these yeasts, primarily the cell diameter, but not their final cell count. Fourier transform infrared spectroscopy showed that the yeast membranes bound the mycotoxins, $C$. utilis in particular. The cell membranes of most yeasts underwent denaturation, except $S$. uvarum exposed to ochratoxin A and zearalenone. In the early stage of fermentation, all mycotoxin-exposed yeasts had lower metabolic activity and biomass growth than controls, but fermentation products and biomass concentrations reached the control levels by the end of the fermentation, except for C. utilis exposed to $20 \mu \mathrm{g} /$ $\mathrm{mL}$ of zearalenone. The adaptive response to mycotoxins suggests that certain yeasts could be used to control mycotoxin concentrations in the production of fermented food and beverages.

Key words: mycotoxins, yeasts, yeast growth, yeast morphology, fermentation, FTIR

\section{INTRODUCTION}

Yeasts have an important use in the production of fermented food and beverages and in biotechnological production such as that of ethanol. However, several stress agents can influence the fermentation performance of yeasts, such as the mycotoxins contaminating the fermentation medium. Even though many yeasts can adapt to unfavourable growth conditions (1-3), these extreme conditions could lead either to cell death or to reduced growth and could also have an adverse effect on the yield and fermentation indicators (4-8).

We know a lot about the use of yeasts in biocontrol, biodegradation, removal or binding of the three major mycotoxins, namely aflatoxin $B_{1}\left(A_{F} B_{1}\right)$, ochratoxin $A(O T A)$ and zearalenone (ZEA) (9-16). However, little is still known about the effects of mycotoxins as stress agents on yeasts, their morphology, growth parameters, metabolic activity, and how they affect fermentation (3,17). Dziuba et al. (5) reported strong inhibition of yeast growth by diacetoxyscirpenol (DAS), a trichothecene mycotoxin, while ZEA and OTA had a weaker effect. Boeira et al. (18-20) reported significant yeast growth inhibition by the Fusarium toxins, ZEA, deoxynivalenol $(\mathrm{DON})$ and fumonisin $\mathrm{B}_{1}\left(\mathrm{FB}_{1}\right)$. Similar findings were reported for the trichothecene T-2 toxin by Foszczyńska and Dziuba $(6)$, and some authors $(5,8,17,21,22)$ have reported that mycotoxins inhibit alcohol dehydrogenase activity and consequently fermentation, lower $\mathrm{CO}_{2}$ release, and affect the production of volatile fermentation byproducts. However, most of these studies were limited to the effects of mycotoxins on the yeast $S$. cerevisiae. Our aim is to expand research to include other important yeasts that are mycotoxin binders such as S. cerevisiae, S. uvarum, C. utilis and K. marxianus, and investigate the effects of AFB ${ }_{1}$, OTA and ZEA on their morphology and metabolic activity.

\section{MATERIALS AND METHODS}

\section{Mycotoxin standards}

AFB $_{1}$, OTA and ZEA standards were purchased from Sigma-Aldrich, Merck (St. Louis, MO, USA). The stock solutions of all mycotoxins were prepared by dissolving crystalline mycotoxins 
in ethanol $\left(2.5 \mathrm{mg} / \mathrm{mL}\right.$ of $\mathrm{AFB}_{1^{\prime}} 2 \mathrm{mg} / \mathrm{mL}$ of OTA and $10 \mathrm{mg} / \mathrm{mL}$ of ZEA). The solutions were filter sterilised $(0.2 \mu \mathrm{m}$; Minisart Syringe Filter, Goettingen, Germany) and stored at $4{ }^{\circ} \mathrm{C}$ until use. Appropriate aliquots of the stock solution were pipetted into a cell culture medium to obtain working solutions of $\mathrm{AFB}_{1}$ of 2.5 and 5 $\mu \mathrm{g} / \mathrm{mL}$, OTA of 2 and $4 \mu \mathrm{g} / \mathrm{mL}$, and ZEA of 2 and $20 \mu \mathrm{g} / \mathrm{mL}$. Pure ethanol was used as control, which had no effect on the yeasts.

\section{Microorganisms}

The yeasts used in this study were Saccharomyces cerevisiae 5, Saccharomyces uvarum 20, Candida utilis 11, and Kluyveromyces marxianus DS12 from the Zagreb University, Faculty of Food Technology and Biotechnology, Croatia. The yeasts were grown in a yeast extract-peptone-glucose (YPG) medium (Merck, Darmstadt, Germany) composed of $2 \%$ glucose, $1 \%$ yeast extract, and $1 \%$ peptone $(\mathrm{pH}=5)$ at $28^{\circ} \mathrm{C}$ for $48 \mathrm{~h}$. The cells were counted on a plate with malt agar (Biolife, Milan, Italy) and expressed as colony-forming units per millilitre $(\mathrm{CFU} / \mathrm{mL})$. The cell concentration was approx. $10^{8} \mathrm{CFU} / \mathrm{mL}$.

\section{Sample preparation}

Under sterile conditions, $1 \mathrm{~mL}$ of yeast suspension $\left(10^{8}\right.$ $\mathrm{CFU} / \mathrm{mL}$ ) was added to Erlenmeyer flasks containing $100 \mathrm{~mL}$ of YPG broth and ethanolic mycotoxin solutions in the following concentrations: 2.5 or $5 \mu \mathrm{g} / \mathrm{mL}$ of $\mathrm{AFB}_{1}, 2$ or $4 \mu \mathrm{g} / \mathrm{mL}$ of OTA and 2 or $20 \mu \mathrm{g} / \mathrm{mL}$ of ZEA. Control flasks contained corresponding volumes of ethanol. All samples were incubated in a shaker (120 rpm; Certomat, Braun, Berlin, Germany) at $30^{\circ} \mathrm{C}$ for $24 \mathrm{~h}$. The samples were collected on incubation hours 0 , $4,6,10,12$ and 24 to determine $\mathrm{pH}$, cell viability, size, density and fermentation products.

At the end of the incubation, the cells were harvested by centrifugation (3500×g for 20 min, Rotofix 32; Hettich, Tuttlingen, Germany) and washed twice with $5 \mathrm{~mL}$ of sterile distilled water, after which the culture biomass was screened for changes in surface properties.

\section{Fourier transform infrared spectroscopy}

Absorptions in the infrared spectral region arise from chemical bond vibrations, which makes the Fourier transform infrared (FTIR) spectroscopy a valuable tool that can identify any changes in the composition and interactions of molecules and their surroundings, such as the changes in the yeast cell wall caused by mycotoxins. We opted for the attenuated total reflection Fourier transform infrared (ATR-FTIR) spectroscopy because it provides good quality spectra with minimum sample preparation, which minimises issues with reproducibility. Suspensions of yeasts and mycotoxins incubated for $24 \mathrm{~h}$ were fed directly to the diamond ATR unit of a Bruker FTIR spectrometer Tensor II (Billerica, MA, USA), and the spectra were recorded against pure water as baseline. The wavelength range was 4000 to $400 \mathrm{~cm}^{-1}$ and the resolution $4 \mathrm{~cm}^{-1}$. The spectra were processed with the Opus v. 5.0 software (23). As the baseline spectrum was influenced by strong water absorptions in the range of 3800 to $3000 \mathrm{~cm}^{-1}$, we normalised it with the methylene stretching peak at $2935 \mathrm{~cm}^{-1}$ and focused the analysis on the so-called fingerprint region (1800 to $600 \mathrm{~cm}^{-1}$ ). This is the region that shows all the characteristic absorptions of all cell wall constituents and all changes in their intensity and position that may reveal interactions with a mycotoxin.

\section{Yeast sensitivity to $A F B_{1}$ OTA and ZEA}

To monitor mycotoxin effects on yeast growth we measured cell absorption using a Unicam Helios $\beta$ spectrophotometer (Cambridge, UK) at $600 \mathrm{~nm}$ on hours $0,4,6,10,12$ and 24 of incubation, while yeast survival was determined by counting the yeast colony-forming units (CFU/mL). Cell size was measured with a stage and ocular micrometer. All measurements were made in triplicate on 100 yeast cells per group (controls and contaminated yeasts).

\section{Determination of yeast metabolites in the fermentation medium}

The presence of fermentation products (ethanol, glycerol and acids) in YPG medium was determined with high-performance liquid chromatography (HPLC, Agilent Technologies, Waldbronn, Germany) after $24 \mathrm{~h}$ of incubation. The samples were centrifuged on a portable centrifuge (Rotofix 32; Hettich) at $3500 \times g$ for 10 min, Carrez reagents (Merck KGaA, Darmstadt, Germany) were added to the supernatant, and the precipitated proteins removed by filtration (24). Metabolite concentrations were measured with a ProStar Varian 230 analytical HPLC (Agilent Technologies, Waldbronn, Germany) equipped with a Varian Pro Star 330 photodiode array (PDA) detector and Varian Pro Star 350 refractive index (RI) detector. For separation, a Varian MetaCarb 87H column (300 mm×6.5 $\mathrm{mm}$ ) was used, heated to $60^{\circ} \mathrm{C}$ in the isocratic mode of elution with $0.005 \mathrm{M}$ sulphuric acid at a constant flow rate of $0.6 \mathrm{~mL} /$ $\mathrm{min}$. Acetic and formic acids were monitored and quantified with the PDA detector and alcohols and glucose with the RI detector. All samples were analysed in triplicate.

\section{Statistical analysis}

All experiments were carried out in triplicate. The results are expressed as mean value \pm standard deviation (S.D.). For analysis the statistical package STATISTICA v. 7.1. was used (25). Averaged data for the mycotoxin effects on cell size and viable cell counts were assessed with the single factor analysis of variance (ANOVA). Differences were considered significant at $\mathrm{p}<0.05$.

\section{RESULTS AND DISCUSSION}

\section{Yeast morphology and growth parameters}

Viable cell counts and cell diameters of yeasts exposed to mycotoxins are shown in Fig. 1 and Fig. 2. In the presence of $2.5 \mu \mathrm{g} / \mathrm{mL}$ of aflatoxin $B_{1}\left(A_{F B}\right)_{1}$, the lag phase of $S$. cerevisiae was prolonged for two hours. Regardless of the applied doses, $\mathrm{AFB}_{1}$ (2.5 or $5.0 \mu \mathrm{g} / \mathrm{mL}$ ) had no significant effect on the cell 

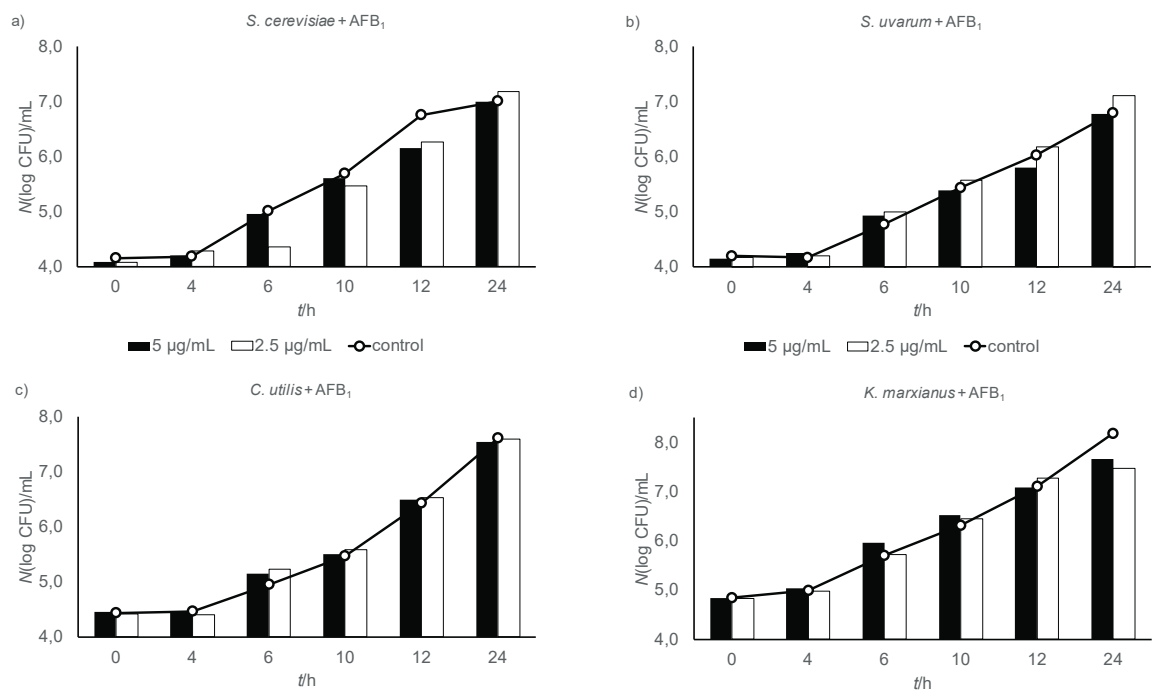

$\mathbf{E} 5 \mathrm{\mu g} / \mathrm{mL} \quad \square 2.5 \mu \mathrm{g} / \mathrm{mL} \quad$ - - -control

- $5 \mu \mathrm{g} / \mathrm{mL} \quad \square 2.5 \mu \mathrm{g} / \mathrm{mL} \quad$-o-control

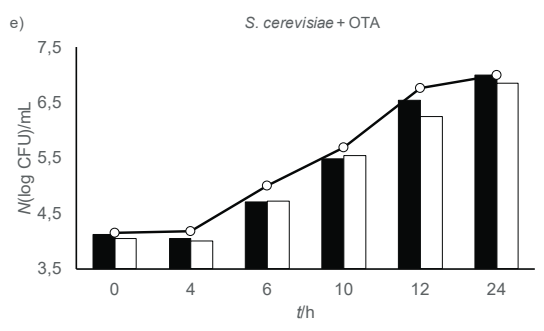

S. uvarum+ OTA

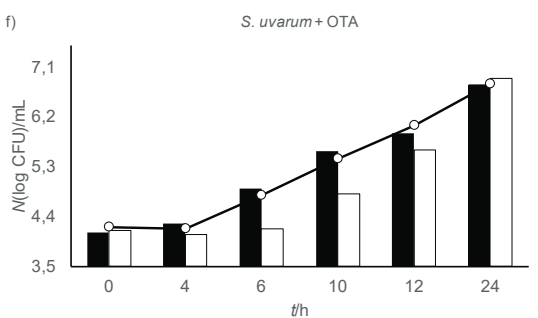

- $4 \mu \mathrm{g} / \mathrm{mL} \quad \square 2 \mu \mathrm{g} / \mathrm{mL} \quad \infty$-control
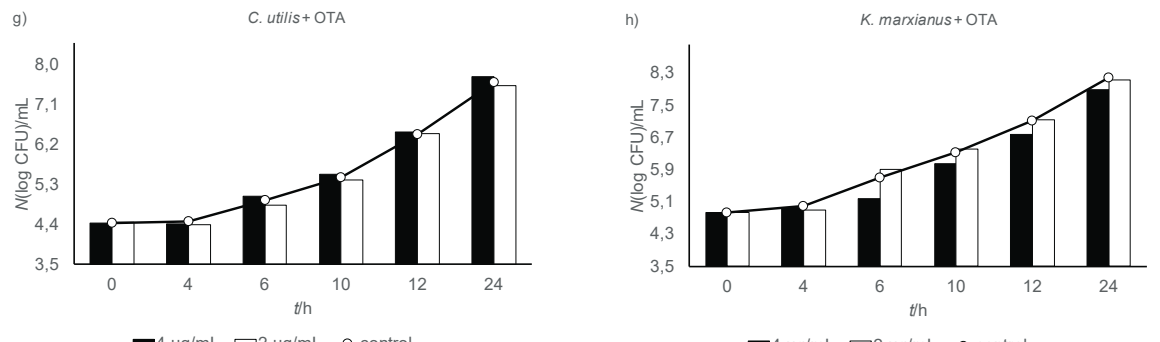

- $4 \mu \mathrm{g} / \mathrm{mL} \quad \square 2 \mu \mathrm{g} / \mathrm{mL} \quad-\infty$ contro

- $4 \mu \mathrm{g} / \mathrm{mL} \quad \square 2 \mu \mathrm{g} / \mathrm{mL} \quad-\infty$-control

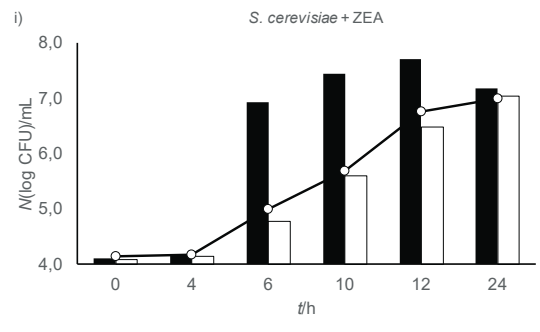

S. uvarum+ZEA

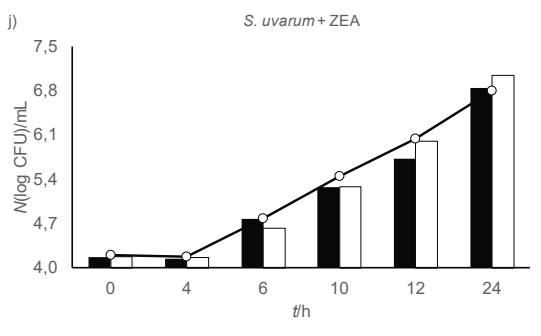

$\mathbf{n} 20 \mu \mathrm{g} / \mathrm{mL} \quad \square 2 \mu \mathrm{g} / \mathrm{mL} \quad-\infty$ control

$\mathbf{n} 20 \mu \mathrm{g} / \mathrm{mL} \quad \square 2 \mu \mathrm{g} / \mathrm{mL} \quad$ - o-control

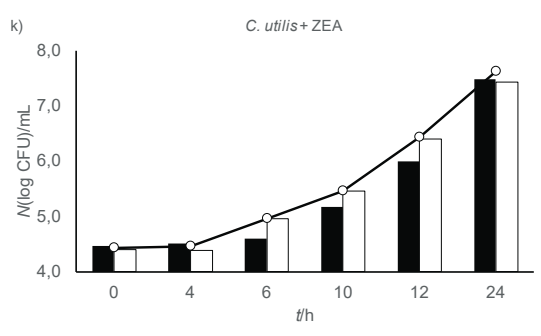

K. marxianus $+Z E A$

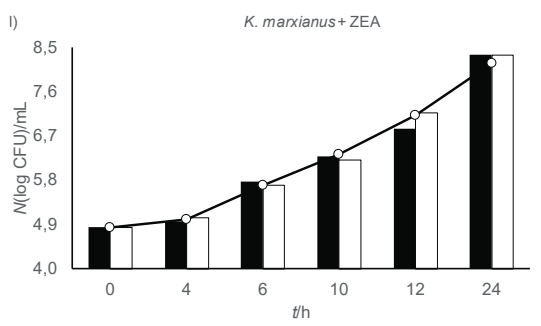

$\boldsymbol{D}_{20} \mu \mathrm{g} / \mathrm{mL} \quad \square 2 \mu \mathrm{g} / \mathrm{mL} \quad$ - - contro

Fig. 1. Viable cell counts of yeasts Saccharomyces cerevisiae, S. uvarum, Candida utilis and Kluyveromyces marxianus exposed to mycotoxins: a-d) aflatoxin $B_{1}\left(A_{F B}\right)$, e-h) ochratoxin $A(O T A)$, and $\mathrm{i}-\mathrm{I}$ ) zearalenone (ZEA) and respective controls 

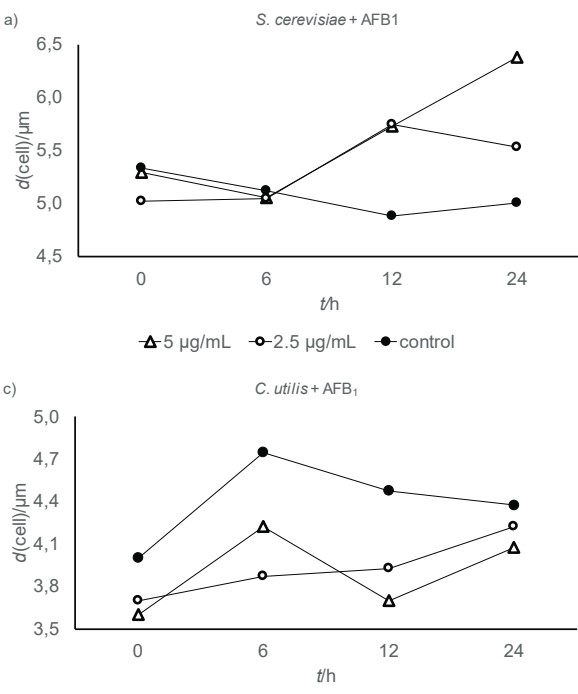

$\Delta-5 \mu \mathrm{g} / \mathrm{mL} \quad-2.5 \mu \mathrm{g} / \mathrm{mL} \quad \bullet$ control

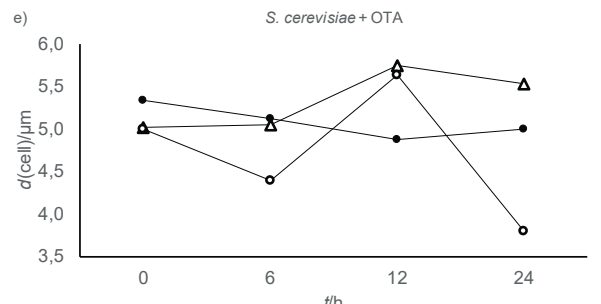

$\Delta-4 \mu \mathrm{g} / \mathrm{mL} \quad-0-2 \mu \mathrm{g} / \mathrm{mL} \quad \bullet$-control

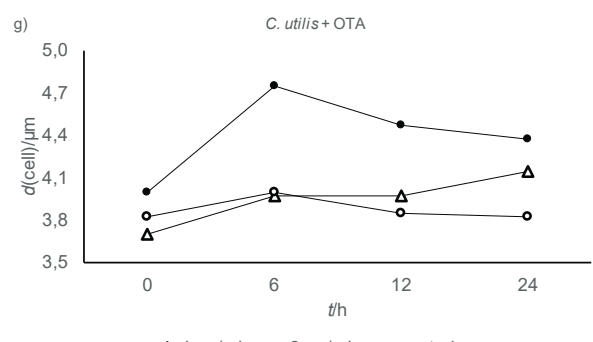

$\Delta-4 \mu \mathrm{g} / \mathrm{mL} \quad-0-2 \mu \mathrm{g} / \mathrm{mL} \quad \bullet$-control

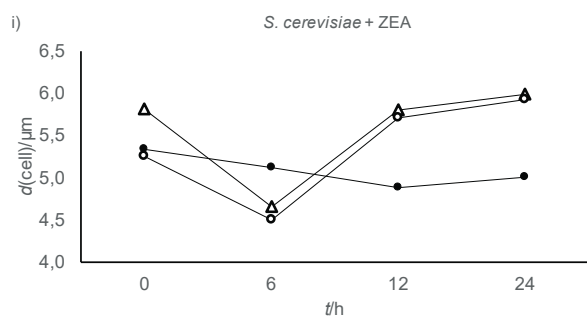

$\Delta-20 \mu \mathrm{g} / \mathrm{mL} \quad-0-2 \mu \mathrm{g} / \mathrm{mL} \quad \bullet$-control

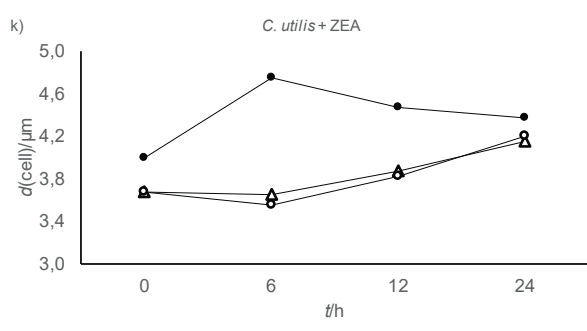

$\Delta-20 \mu \mathrm{g} / \mathrm{mL} \quad-\mathbf{-}-2 \mu \mathrm{g} / \mathrm{mL} \quad \bullet$-control

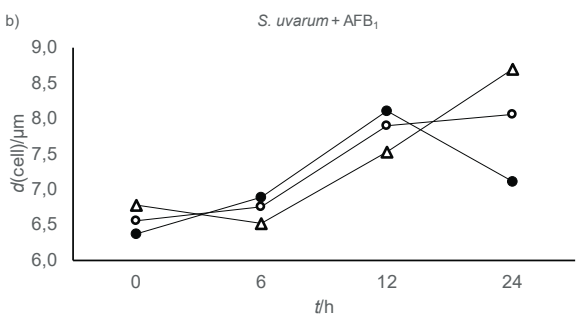

$\Delta-5 \mu \mathrm{g} / \mathrm{mL} \quad-\mathbf{0}-2.5 \mu \mathrm{g} / \mathrm{mL} \quad \bullet$ control

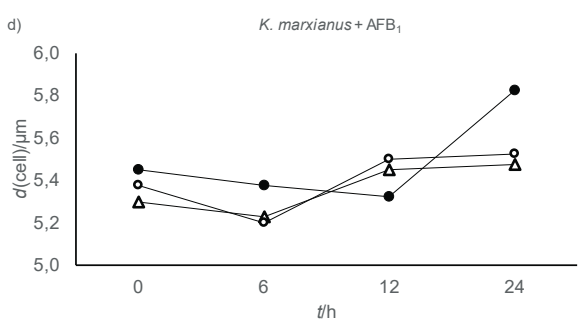

$\Delta-5 \mu \mathrm{g} / \mathrm{mL} \quad-0-2.5 \mu \mathrm{g} / \mathrm{mL} \quad \bullet$ control

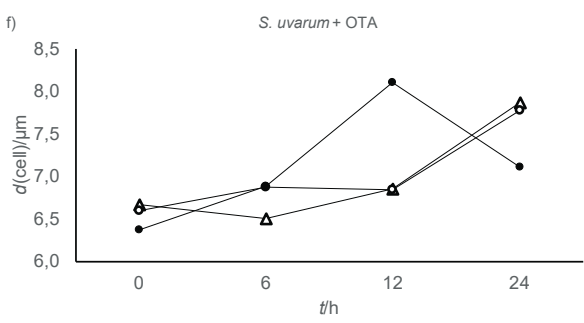

$\Delta-4 \mu \mathrm{g} / \mathrm{mL} \quad-2-2 \mu \mathrm{g} / \mathrm{mL} \quad \bullet$ control

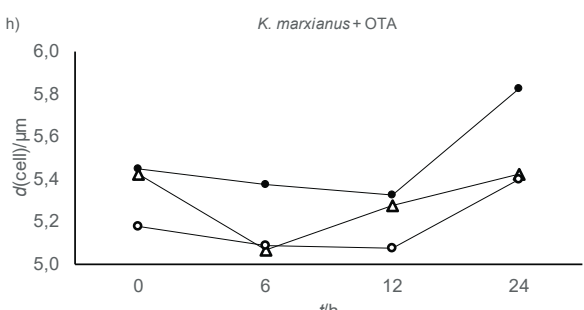

$\Delta-4 \mu \mathrm{g} / \mathrm{mL} \quad-0-2 \mu \mathrm{g} / \mathrm{mL} \quad \bullet$ control

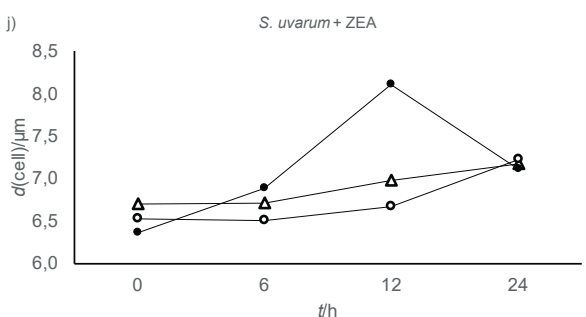

$\Delta-20 \mu \mathrm{g} / \mathrm{mL} \quad-0-2 \mu \mathrm{g} / \mathrm{mL} \quad \bullet$-control

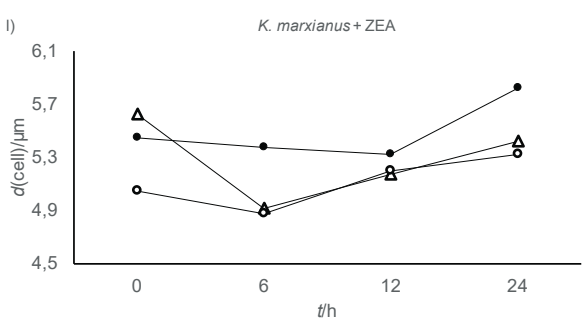

$\Delta-20 \mu \mathrm{g} / \mathrm{mL} \quad-2-2 \mu \mathrm{g} / \mathrm{mL} \quad \bullet$ control

Fig. 2. Cell diameters of yeasts Saccharomyces cerevisiae, S. uvarum, Candida utilis and Kluyveromyces marxianus exposed to mycotoxins: a-d) aflatoxin $B_{1}\left(A F B_{1}\right)$, e-h) ochratoxin $A(O T A)$, and $\left.\mathrm{i}-\mathrm{I}\right)$ zearalenon (ZEA) and respective controls 
count of any yeast strain (Figs. 1a-d). Despite visible differences in morphology (Figs. 2a-d), the AFB -treated S. uvarum and $K$. marxianus samples did not differ significantly in cell size from control. The exception are the samples of $C$. utilis treated with $2.5 \mu \mathrm{g} / \mathrm{mL}$ of $\mathrm{AFB}_{1}(\mathrm{p}<0.05)$.

The 2-hour prolongation of the lag phase in S. uvarum treated with $2 \mu \mathrm{g} / \mathrm{mL}$ of ochratoxin (OTA) was accompanied by a 20 $15 \%$ cell count drop on the 6th and 10th hour of incubation (Fig. 1f). At the concentration of $4 \mu \mathrm{g} / \mathrm{mL}$ of OTA also prolonged the lag phase for two hours of K. marxianus (Fig. 1h) but did not affect the growth of $C$. utilis (Fig. 1g). However, by the end of the 24-hour incubation, the final cell counts of the yeasts exposed to OTA were not significantly lower than control. After six hours of incubation, both OTA concentrations significantly reduced the cell diameter of $C$. utilis ( $p<0.05$; Fig. $2 \mathrm{~g}$ ), but their effect differed between the two species from the same genus (Saccharomyces) (Fig. 2e and Fig. 2f, respectively).

In contrast to OTA, zearalenon (ZEA) did not affect the growth of S. uvarum and K. marxianus (Fig. $1 \mathrm{j}$ and Fig. 11, respectively). However, at concentration of $20 \mu \mathrm{g} / \mathrm{mL}$ it stimulated the growth of $S$. cerevisiae up until the 12th hour of incubation, when the cell count peaked (5.2·107 CFU/mL; Fig. 1i). These differences were not statistically significant, but they do tell us that $S$. cerevisiae is susceptible to higher doses of ZEA. ZEA at the concentration of $20 \mu \mathrm{g} / \mathrm{mL}$ prolonged the lag phase of C. utilis for $2 \mathrm{~h}$ (Fig. $1 \mathrm{k}$ ), and Fig. $2 \mathrm{k}$ shows the effects of ZEA on yeast morphology (cell size) over the $24 \mathrm{~h}$ of incubation. Both doses reduced the cell diameter of S. uvarum by $15-20 \%$ (Fig. 2j). The S. cerevisiae cells at $24 \mathrm{~h}$ were larger about $10-25 \%$ than control regardless of the ZEA concentration. In the first six hours of incubation, ZEA significantly reduced the size of $C$. utilis compared to control (Fig. 2k). Similar were the effects on K. marxianus (Fig. 2l).

Our cell counts (Figs. 1a-I) show that the tested yeast strains can adapt to the presence of mycotoxins, given enough time ( $24 \mathrm{~h}$ in our case). With AFB their growth pattern was even similar to that of the uncontaminated samples (Figs. 1a-d), while OTA and ZEA had a stronger, yet insignificant effect (Figs. 1e-h and Figs. 1i-I, respectively). Similar results have been reported by other authors $(5-7,26)$, who showed that $A F B_{1}$ did not inhibit the growth of $K$. marxianus and found a weak effect of ZEA and no effect of OTA on the viability of the brewing yeast strains of Saccharomyces spp.

Boeira et al. $(18,19,27)$ observed that Fusarium mycotoxins affected the growth of $S$. cerevisiae lager and ale strains and that the inhibiting effect depended on the toxin type and concentration, yeast strain, and time and temperature of incubation. Yeast sensitivity to mycotoxins seems to vary with the structural composition of the plasma membrane and the ability of mycotoxins to bind to the cell wall and penetrate the cell $(15,20)$. Mycotoxin effects depend not only on the structure of the cell membrane, which can differ even in the same yeast species, but also on its integrity, which is influenced by a number of factors (5). Changes in cell size in our study could be attributed to mycotoxin binding to the cell wall surface, because it is known that viable yeast cells, dead cells, and cell wall products ( $\beta$-D-glucans, glucomannans and mannan-oligosaccharide) have a high capacity to adsorb mycotoxins from the environment $(28,29)$. On the other hand, changes in cell size could be related to the ability of a mycotoxin to penetrate yeast cell membrane. It is well known that cell size can change extracellular conditions (30). Limited nutrients or physical or chemical stressors can induce direct or indirect structural changes in proteins, which can result in protein aggregation and, subsequently, in dysfunctional cell compartments (31). Therefore, cell size can be an important selective property for survival in changing, nutrient-limited, and/or contaminated environments $(30,32)$. In all our yeasts, mycotoxins affected their cell diameter (Figs. 2a-I).

Table 1 shows the mycotoxin effects on yeast biomass concentration at hours 12 and 24 of incubation. AFB $_{1}$ affected it minimally, while OTA and ZEA reduced it significantly, especially in C. utilis ( $20 \mu \mathrm{g} / \mathrm{mL}$ of ZEA at $12 \mathrm{~h}$ ). Even though all tested yeasts grew more slowly and the yeast growth phases were prolonged in the presence of toxins in the first 12 hours, their final biomass concentrations were the same as in controls.

Table 1. Yeast biomass in YPG medium with and without aflatoxin $\mathrm{B}_{1}\left(\mathrm{AFB}_{1}\right)$, ochratoxin $\mathrm{A}(\mathrm{OTA})$ and zearalenon (ZEA) addition (mean value \pm S.D.)

\begin{tabular}{|c|c|c|c|c|c|c|c|c|c|}
\hline \multirow{4}{*}{ Mycotoxin } & \multirow{4}{*}{$\frac{\gamma(\text { mycotoxin })}{\mu \mathrm{g} / \mathrm{mL}}$} & \multicolumn{8}{|c|}{$A_{600 \mathrm{~nm}}$ (yeast) } \\
\hline & & \multicolumn{8}{|c|}{$t / h$} \\
\hline & & 12 & 24 & 12 & 24 & 12 & 24 & 12 & 24 \\
\hline & & \multicolumn{2}{|c|}{ S. cerevisiae } & \multicolumn{2}{|c|}{ S. uvarum } & \multicolumn{2}{|c|}{ C. utilis } & \multicolumn{2}{|c|}{ K. marxianus } \\
\hline Control & - & $\begin{array}{c}0.838 \pm \\
0.018\end{array}$ & $\begin{array}{c}1.987 \pm \\
0.007\end{array}$ & $\begin{array}{c}0.722 \pm \\
0.006\end{array}$ & $\begin{array}{c}1.923 \pm \\
0.013\end{array}$ & $\begin{array}{c}0.987 \pm \\
0.008\end{array}$ & $\begin{array}{c}2.225 \pm \\
0.011\end{array}$ & $\begin{array}{c}1.602 \pm \\
0.014\end{array}$ & $\begin{array}{c}1.952 \pm \\
0.007\end{array}$ \\
\hline $\mathrm{AFB}_{1}$ & 5.0 & $\begin{array}{c}0.812 \pm \\
0.008\end{array}$ & $\begin{array}{c}1.910 \pm \\
0.025\end{array}$ & $\begin{array}{c}0.670 \pm \\
0.013\end{array}$ & $\begin{array}{c}1.925 \pm \\
0.022\end{array}$ & $\begin{array}{c}0.804 \pm \\
0.006\end{array}$ & $\begin{array}{c}2.217 \pm \\
0.009\end{array}$ & $\begin{array}{c}1.543 \pm \\
0.003\end{array}$ & $\begin{array}{r}1.938 \pm \\
0.009\end{array}$ \\
\hline $\mathrm{AFB}_{1}$ & 2.5 & $\begin{array}{c}0.757 \pm \\
0.010\end{array}$ & $\begin{array}{c}1.993 \pm \\
0.008\end{array}$ & $\begin{array}{c}0.678 \pm \\
0.024\end{array}$ & $\begin{array}{c}1.920 \pm \\
0.003\end{array}$ & $\begin{array}{c}0.817 \pm \\
0.013\end{array}$ & $\begin{array}{c}2.239 \pm \\
0.011\end{array}$ & $\begin{array}{c}1.504 \pm \\
0.006\end{array}$ & $\begin{array}{r}1.981 \pm \\
0.012\end{array}$ \\
\hline OTA & 4.0 & $\begin{array}{c}0.763 \pm \\
0.011\end{array}$ & $\begin{array}{c}1.971 \pm \\
0.004\end{array}$ & $\begin{array}{c}0.577 \pm \\
0.002\end{array}$ & $\begin{array}{c}1.920 \pm \\
0.007\end{array}$ & $\begin{array}{c}0.740 \pm \\
0.010\end{array}$ & $\begin{array}{c}2.237 \pm \\
0.007\end{array}$ & $\begin{array}{c}1.322 \pm \\
0.014\end{array}$ & $\begin{array}{c}1.943+ \\
0.008\end{array}$ \\
\hline OTA & 2.0 & $\begin{array}{c}0.700 \pm \\
0.016\end{array}$ & $\begin{array}{c}1.961 \pm \\
0.013\end{array}$ & $\begin{array}{c}0.624 \pm \\
0.018\end{array}$ & $\begin{array}{c}1.922 \pm \\
0.030\end{array}$ & $\begin{array}{c}0.769 \pm \\
0.013\end{array}$ & $\begin{array}{c}2.164 \pm \\
0.009\end{array}$ & $\begin{array}{c}1.529 \pm \\
0.008\end{array}$ & $\begin{array}{r}1.948 \pm \\
0.008\end{array}$ \\
\hline ZEA & 20 & $\begin{array}{c}0.728 \pm \\
0.023\end{array}$ & $\begin{array}{c}1.969 \pm \\
0.019\end{array}$ & $\begin{array}{c}0.584 \pm \\
0.033\end{array}$ & $\begin{array}{c}1.861 \pm \\
0.022\end{array}$ & $\begin{array}{c}0.482 \pm \\
0.024\end{array}$ & $\begin{array}{c}2.005 \pm \\
0.018\end{array}$ & $\begin{array}{c}1.409 \pm \\
0.013\end{array}$ & $\begin{array}{c}1.929 \pm \\
0.010\end{array}$ \\
\hline ZEA & 2.0 & $\begin{array}{c}0.755 \pm \\
0.009\end{array}$ & $\begin{array}{c}1.988 \pm \\
0.003 \\
\end{array}$ & $\begin{array}{c}0.567 \pm \\
0.008\end{array}$ & $\begin{array}{c}1.910 \pm \\
0.013 \\
\end{array}$ & $\begin{array}{c}0.773 \pm \\
0.013 \\
\end{array}$ & $\begin{array}{c}2.174 \pm \\
0.033\end{array}$ & $\begin{array}{c}1.497 \pm \\
0.008 \\
\end{array}$ & $\begin{array}{r}1.880 \pm \\
0.012 \\
\end{array}$ \\
\hline
\end{tabular}

S.D.=standard deviation of triplicate measurements, YPG=yeast extract-peptone-glucose 


\section{Mycotoxin effects on yeast cell wall}

No new absorptions appeared in the spectra of the mycotoxin-exposed yeast samples (Figs. 3a-d), but some absorptions changed intensity and position. Only the spectra of the S. uvarum exposed to AFB were almost identical to control (Fig. 3b). The main changes in the presence of mycotoxins occurred at 1635 and $1548 \mathrm{~cm}^{-1}$, i.e. in the amide I and II bands and in some cases at $1243 \mathrm{~cm}^{-1}$, attributed to the amide III band. Another significant change in absorption was caused by the $\mathrm{C}-\mathrm{O}$ stretching at $1078 \mathrm{~cm}^{-1}$. The most pronounced changes in absorption intensities were observed when C. utilis was exposed to AFB (Fig. 3c), affecting both the amide and $\mathrm{C}-\mathrm{O}$ bond stretching absorptions. These changes in intensities corresponded to AFB concen- $_{1}$ trations. Changes in the amide absorptions of the ZEA-exposed S. cerevisiae and S. uvarum were less significant (Fig. $3 \mathrm{a}$ and Fig. 3b, respectively), but significant changes were determined in the $\mathrm{C}-\mathrm{O}$ bond stretching in the spectra of all exposed K. marxianus samples (Fig. $3 \mathrm{~d}$ ) and in the C. utilis exposed to OTA (Fig. 3c). C-O bond stretching intensity
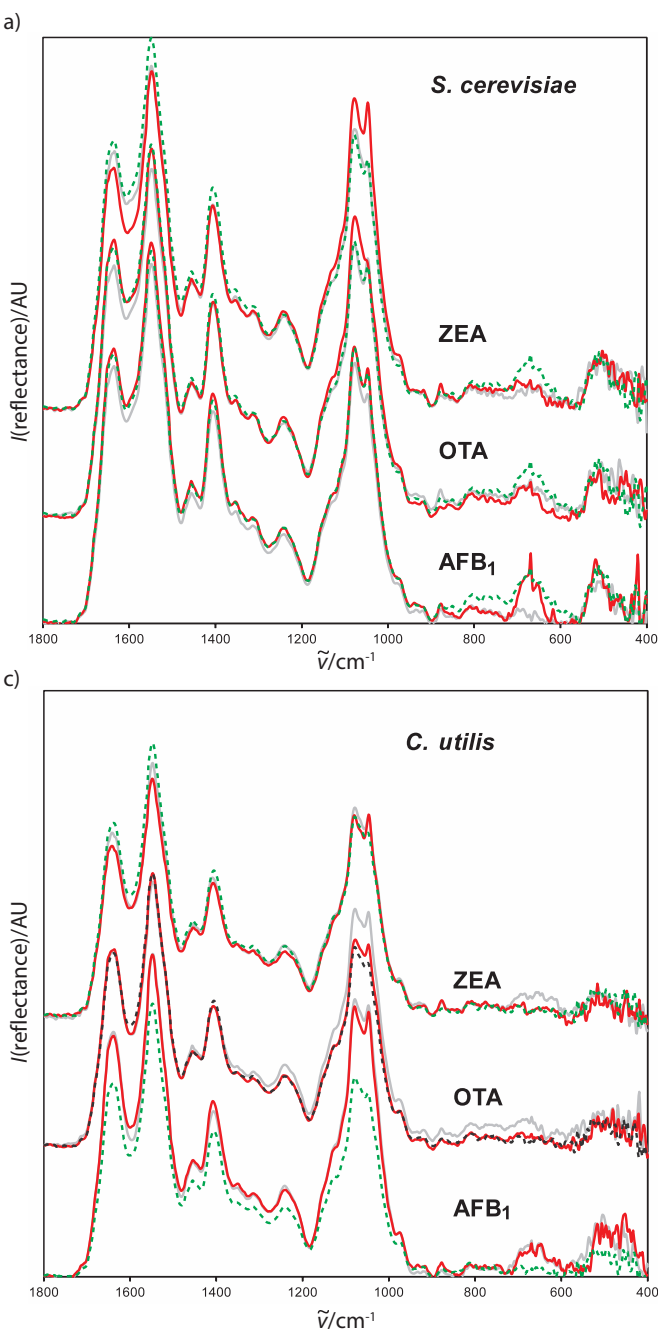

slightly increased in the spectra of the $S$. cerevisiae and $S$. uvarum exposed to ZEA (Fig. 3a and Fig. 3b, respectively), C. utilis exposed to OTA and $\mathrm{AFB}_{1}$ (Fig. $3 \mathrm{C}$ ), and S. uvarum exposed to $A F B_{1}$ (Fig. 3b).

Judging by the cell diameter and FTIR spectroscopy, $S$. uvarum was the only yeast unaffected by the presence of $A_{1} B_{1}$ (Fig. $2 \mathrm{~b}$ and Fig. 3b, respectively). In all other yeasts the mycotoxins caused at least some changes in the FTIR spectra (Fig. 3a, Fig. 3c and Fig. 3d). These changes depended on both yeast and mycotoxin type and mycotoxin concentration. The changes in the amide I, II and III absorption intensities reflect the state of protein molecules, while the $\mathrm{C}-\mathrm{O}$ stretching absorption tells about the state of carbohydrates constituting yeast cell wall. Additionally, an increase in the amide I/II intensity ratio (Table 2 ) indicates protein denaturation, which was observed to some extent in almost all of the exposed yeasts. Judging by the amide I/II intensity ratio, the lowest denaturation was observed in the $C$. utilis exposed to OTA and the $S$. cerevisiae exposed to $\mathrm{AFB}_{1}$, while the greatest denaturation occurred in the $K$. marxianus exposed to OTA.
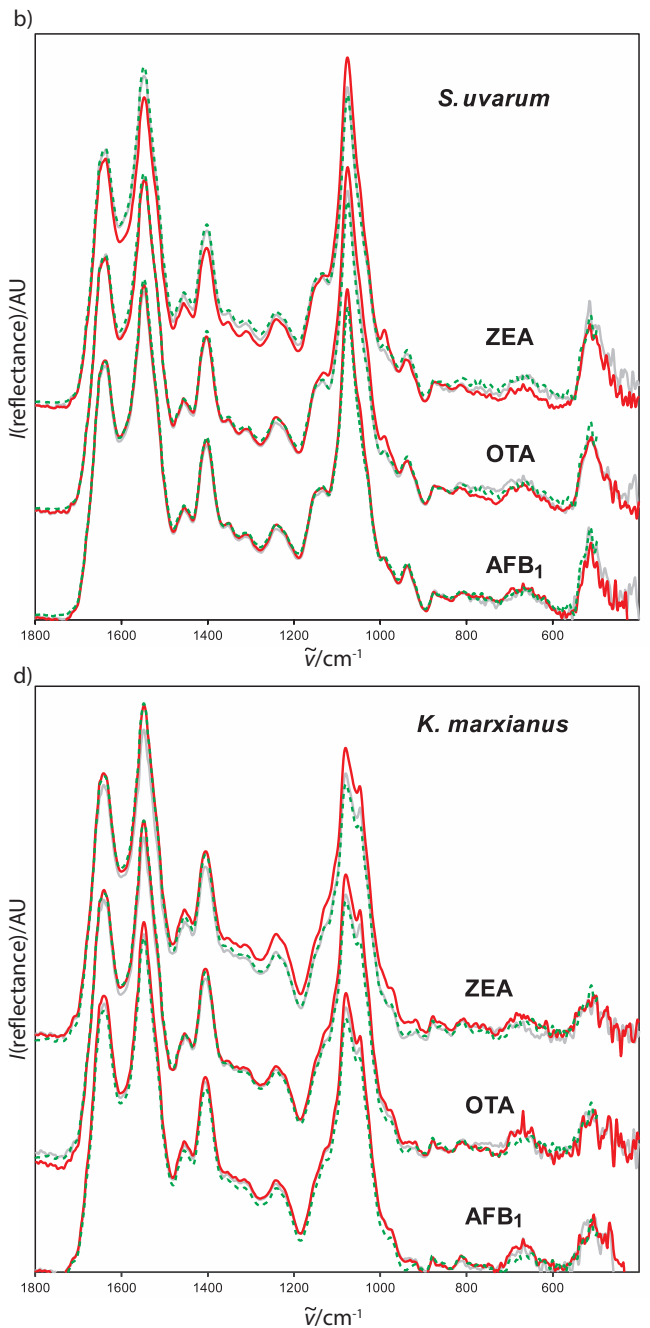

Fig. 3. Fingerprint segments of ATR-FTIR spectra of yeast strains exposed to mycotoxins: dashed green line=control, grey line=lower mycotoxin concentration, red line=higher mycotoxin concentration. $Z E A=$ zearalenon, OTA=ochratoxin, $A_{F B}=$ aflatoxin $B_{1}$ 
Table 2. ATR-FTIR of yeast strains exposed to mycotoxins: the wavenumber and intensity ratios of the amide I and II

\begin{tabular}{|c|c|c|c|c|c|c|}
\hline Mycotoxin & $\frac{\gamma \text { (mycotoxin) }}{\mu \mathrm{g} / \mathrm{mL}}$ & & S. cerevisiae & S. uvarum & C. utilis & K. marxianus \\
\hline \multirow{2}{*}{ Control } & \multirow{2}{*}{-} & (1) & 1635,1549 & 1636,1548 & 1638,1548 & 1640,1548 \\
\hline & & (2) & 0.710 & 0.750 & 0.710 & 0.759 \\
\hline \multirow{2}{*}{$\mathrm{AFB}_{1}$} & \multirow{2}{*}{5.0} & (1) & 1636,1549 & 1637,1548 & 1638,1548 & 1641,1548 \\
\hline & & $(2)$ & 0.722 & 0.774 & 0.720 & 0.800 \\
\hline \multirow{2}{*}{$\mathrm{AFB}_{1}$} & \multirow{2}{*}{2.5} & (1) & 1635,1549 & 1637,1548 & 1639,1547 & 1640,1548 \\
\hline & & $(2)$ & 0.706 & 0.774 & 0.760 & 0.793 \\
\hline \multirow{2}{*}{ OTA } & \multirow{2}{*}{4.0} & (1) & 1635, 1548 & 1637,1546 & 1637,1548 & 1642,1548 \\
\hline & & (2) & 0.743 & 0.774 & 0.714 & 0.820 \\
\hline \multirow{2}{*}{ OTA } & \multirow{2}{*}{2.0} & (1) & 1635,1548 & 1636,1545 & 1637,1547 & 1641,1548 \\
\hline & & $(2)$ & 0.727 & 0.774 & 0.750 & 0.846 \\
\hline \multirow{2}{*}{ ZEA } & \multirow{2}{*}{20} & (1) & 1635,1548 & 1637,1547 & 1642,1548 & 1640,1548 \\
\hline & & $(2)$ & 0.719 & 0.774 & 0.722 & 0.793 \\
\hline \multirow{2}{*}{ ZEA } & \multirow{2}{*}{2.0} & (1) & 1634,1548 & 1637,1548 & 1641,1548 & 1641,1548 \\
\hline & & (2) & 0.750 & 0.774 & 0.737 & 0.793 \\
\hline
\end{tabular}

(1) $\tilde{V}\left(\right.$ amide I and II)/cm ${ }^{-1}$, (2) I(amide I)/I(amide II), AFB $=$ aflatoxin $B_{1}, O T A=$ ochratoxin $A, Z E A=$ zearalenon

Proteins and carbohydrates of the yeast cell wall may be included in mycotoxin binding (33). This is in agreement with the variations in FTIR absorption intensities in the exposed yeasts in comparison to the corresponding controls. The most pronounced increase in absorption intensities in the $C$. utilis exposed to $\mathrm{AFB}_{1}$ (Table 2 ) indicates a strong interaction between the yeast cell wall protein and carbohydrate components and the mycotoxin. This suggests that $C$. utilis has a greater mycotoxin-binding potential than other yeasts, whose less pronounced spectral changes imply greater denaturation than interaction with mycotoxins.

\section{Fermentation by-products}

Table 3 summarises HPLC measurements of the fermentation byproducts and residual glucose after $24 \mathrm{~h}$ of yeast growth and fermentation in YPG medium with and without mycotoxins. All metabolites except ethanol were analysed at the end of fermentation because their concentration was below the detection limit on the 12th hour of fermentation. Just like with the cell counts, the mycotoxins did not significantly affect the final concentration of the metabolites. Glucose was completely depleted in all but C. utilis exposed to $20 \mu \mathrm{g} / \mathrm{mL}$ of ZEA. Glycerol concentrations ranged from 0.07 to $0.267 \mathrm{mg} /$ $\mathrm{mL}$, regardless of exposure. Differences in acid concentrations between the exposed and control yeasts were not significant. However, the yeasts were not entirely resistant to the mycotoxins. Ethanol synthesis was slowed down, especially by ZEA. The most sensitive to ZEA was $C$. utilis, but it was also sensitive to OTA at $4 \mu \mathrm{g} / \mathrm{mL}$. These two toxins also slowed down ethanol synthesis by S. uvarum and K. marxianus. The most resistant fermentation was that of S. cerevisiae.

Table 3. Fermentation products and residual glucose after 24 hours of yeast growth and fermentation in YPG medium with and without a mycotoxin (mean value \pm S.D.)

\begin{tabular}{|c|c|c|c|c|c|c|c|c|}
\hline \multirow{2}{*}{ Mycotoxin } & \multirow{2}{*}{$\frac{\gamma(\text { mycotoxin }) /}{\mu \mathrm{g} / \mathrm{mL}}$} & \multicolumn{5}{|c|}{$\gamma /(\mathrm{mg} / \mathrm{mL})$} & \multicolumn{2}{|c|}{$\varphi($ ethanol $) / \%$} \\
\hline & & Glucose & Glycerol & Acetic acid & Formic acid & 2-Propanol & 12th hour & 24th hour \\
\hline $\begin{array}{l}\text { S. cerevisiae } \\
\text { (control) }\end{array}$ & - & n.d. & $0.090 \pm 0.01$ & $0.062 \pm 0.005$ & n.d. & n.d. & $0.84 \pm 0.04$ & $1.99 \pm 0.02$ \\
\hline $\mathrm{AFB}_{1}$ & 5.0 & n.d. & $0.099 \pm 0.04$ & $0.090 \pm 0.006$ & n.d. & n.d. & $0.81 \pm 0.02$ & $1.91 \pm 0.01$ \\
\hline $\mathrm{AFB}_{1}$ & 2.5 & n.d. & $0.079 \pm 0.09$ & $0.07 \pm 0.01$ & n.d. & n.d. & $0.76 \pm 0.03$ & $1.993 \pm 0.009$ \\
\hline OTA & 4.0 & n.d. & $0.08 \pm 0.01$ & $0.08 \pm 0.02$ & n.d. & n.d. & $0.76 \pm 0.05$ & $1.97 \pm 0.01$ \\
\hline OTA & 2.0 & n.d. & $0.07 \pm 0.015$ & $0.06 \pm 0.01$ & n.d. & n.d. & $0.70 \pm 0.03$ & $1.961 \pm 0.007$ \\
\hline ZEA & 20 & n.d. & $0.07 \pm 0.01$ & $0.077 \pm 0.009$ & n.d. & n.d. & $0.73 \pm 0.01$ & $1.97 \pm 0.02$ \\
\hline ZEA & 2.0 & n.d. & $0.08 \pm 0.01$ & $0.067 \pm 0.009$ & n.d. & n.d. & $0.76 \pm 0.02$ & $1.99 \pm 0.02$ \\
\hline $\begin{array}{l}\text { S. uvarum } \\
\text { (control) }\end{array}$ & - & n.d. & $0.12 \pm 0.02$ & $0.15 \pm 0.02$ & $0.057 \pm 0.005$ & n.d. & $0.72 \pm 0.02$ & $1.923 \pm 0.004$ \\
\hline $\mathrm{AFB}_{1}$ & 5.0 & n.d. & $0.12 \pm 0.01$ & $0.20 \pm 0.02$ & $0.063 \pm 0.003$ & n.d. & $0.67 \pm 0.03$ & $1.925 \pm 0.009$ \\
\hline $\mathrm{AFB}_{1}$ & 2.5 & n.d. & $0.121 \pm 0.004$ & $0.15 \pm 0.02$ & $0.057 \pm 0.006$ & n.d. & $0.68 \pm 0.03$ & $1.92 \pm 0.01$ \\
\hline OTA & 4.0 & n.d. & $0.10 \pm 0.02$ & $0.15 \pm 0.02$ & $0.058 \pm 0.008$ & n.d. & $0.58 \pm 0.01$ & $1.92 \pm 0.02$ \\
\hline OTA & 2.0 & n.d. & $0.08 \pm 0.03$ & $0.10 \pm 0.03$ & $0.062 \pm 0.003$ & n.d. & $0.62 \pm 0.02$ & $1.92 \pm 0.01$ \\
\hline ZEA & 20 & n.d. & $0.121 \pm 0.006$ & $0.13 \pm 0.02$ & $0.06 \pm 0.01$ & n.d. & $0.58 \pm 0.03$ & $1.861 \pm 0.009$ \\
\hline ZEA & 2.0 & n.d. & $0.10 \pm 0.01$ & $0.21 \pm 0.03$ & $0.054 \pm 0.002$ & n.d. & $0.57 \pm 0.03$ & $1.910 \pm 0.008$ \\
\hline
\end{tabular}


Table 3. continued

\begin{tabular}{|c|c|c|c|c|c|c|c|c|}
\hline \multirow{2}{*}{ Mycotoxin } & \multirow{2}{*}{$\frac{\gamma(\text { mycotoxin }) /}{\mu \mathrm{g} / \mathrm{mL}}$} & \multicolumn{5}{|c|}{$\gamma /(\mathrm{mg} / \mathrm{mL})$} & \multicolumn{2}{|c|}{$\varphi($ ethanol $) / \%$} \\
\hline & & Glucose & Glycerol & Acetic acid & Formic acid & 2-Propanol & 12th hour & 24th hour \\
\hline $\begin{array}{l}\text { C. utilis } \\
\text { (control) }\end{array}$ & - & n.d. & $0.273 \pm 0.001$ & $0.08 \pm 0.008$ & $0.09 \pm 0.02$ & n.d. & $0.99 \pm 0.02$ & $2.22 \pm 0.01$ \\
\hline $\mathrm{AFB}_{1}$ & 5.0 & n.d. & $0.267 \pm 0.008$ & $0.14 \pm 0.02$ & $0.07 \pm 0.01$ & n.d. & $0.80 \pm 0.02$ & $2.22 \pm 0.01$ \\
\hline $\mathrm{AFB}_{1}$ & 2.5 & n.d. & $0.258 \pm 0.007$ & $0.12 \pm 0.02$ & $0.09 \pm 0.01$ & n.d. & $0.82 \pm 0.01$ & $2.24 \pm 0.02$ \\
\hline OTA & 4.0 & n.d. & $0.25 \pm 0.01$ & $0.17 \pm 0.01$ & $0.095 \pm 0.009$ & n.d. & $0.74 \pm 0.01$ & $2.24 \pm 0.02$ \\
\hline OTA & 2.0 & n.d. & $0.22 \pm 0.02$ & $0.23 \pm 0.03$ & $0.08 \pm 0.01$ & n.d. & $0.77 \pm 0.01$ & $2.16 \pm 0.01$ \\
\hline ZEA & 20 & $0.56 \pm 0.03$ & $0.221 \pm 0.005$ & $0.14 \pm 0.01$ & $0.073 \pm 0.002$ & n.d. & $0.48 \pm 0.02$ & $2.00 \pm 0.02$ \\
\hline ZEA & 2.0 & n.d. & $0.265 \pm 0.008$ & $0.15 \pm 0.02$ & $0.079 \pm 0.007$ & n.d. & $0.77 \pm 0.02$ & $2.174 \pm 0.007$ \\
\hline $\begin{array}{c}\text { K. marxianus } \\
\text { (control) }\end{array}$ & - & n.d. & $0.062 \pm 0.005$ & $0.09 \pm 0.01$ & $0.074 \pm 0.009$ & n.d. & $1.602 \pm 0.008$ & $1.952 \pm 0.007$ \\
\hline $\mathrm{AFB}_{1}$ & 5.0 & n.d. & $0.15 \pm 0.03$ & $0.08 \pm 0.02$ & $0.06 \pm 0.01$ & n.d. & $1.54 \pm 0.01$ & $1.94 \pm 0.01$ \\
\hline $\mathrm{AFB}_{1}$ & 2.5 & n.d. & $0.13 \pm 0.02$ & $0.11 \pm 0.01$ & $0.08 \pm 0.01$ & n.d. & $1.50 \pm 0.01$ & $1.98 \pm 0.02$ \\
\hline OTA & 4.0 & n.d. & $0.09 \pm 0.02$ & $0.10 \pm 0.02$ & $0.083 \pm 0.009$ & $0.058 \pm 0.016$ & $1.32 \pm 0.03$ & $1.94 \pm 0.01$ \\
\hline OTA & 2.0 & n.d. & $0.08 \pm 0.01$ & $0.097 \pm 0.007$ & $0.057 \pm 0.008$ & n.d. & $1.529 \pm 0.009$ & $1.948 \pm 0.008$ \\
\hline ZEA & 20 & n.d. & $0.09 \pm 0.01$ & $0.12 \pm 0.02$ & $0.06 \pm 0.01$ & $0.039 \pm 0.010$ & $1.41 \pm 0.02$ & $1.929 \pm 0.004$ \\
\hline ZEA & 2.0 & n.d. & $0.11 \pm 0.02$ & $0.093 \pm 0.009$ & $0.06 \pm 0.02$ & n.d. & $1.50 \pm 0.03$ & $1.880 \pm 0.007$ \\
\hline
\end{tabular}

n.d.=not detected, S.D.=standard deviation of triplicate measurements, YPG=yeast extract-peptone-glucose, $A_{F} B_{1}=$ aflatoxin $B_{1}, O T A=o c h r a t o x i n$ A, ZEA=zearalenon

Fermentation and the final concentrations of byproducts in the contaminated media confirm the implications of the yeast cell counts. Our results suggest that yeast cells and their important enzymes exhibit some sensitivity to mycotoxins but are also able to adapt. Several authors obtained similar results. Kłosowski et al. (8) detected statistically significant effect of $\mathrm{AFB}_{1}, \mathrm{OTA}$, and especially ZEA on the first and the main fermentation phase of maize mashes with $S$. cerevisiae and also observed that the effect gradually vanished in successive hours. Pfliegler et al. (16) singled out several mechanisms of mycotoxin action on yeast cell metabolism. One is the standstill of the eukaryotic DNA replication caused by ZEA, citrinin and patulin, which leads to a delay in the cell cycle. Another is that citrinin and patulin can also cause changes in the sterol composition and interact with free sulphhydryl groups of plasma membrane proteins, which leads to dose-dependent membrane fluidisation. Mycotoxins, including AFB ${ }_{1}$ OTA and ZEA investigated in this paper, can inhibit the enzymes of fermentation, delay growth kinetics and cause oxidative stress (8).

All these effects slow down yeast growth and, consequently, fermentation. However, many yeast genes respond by encoding for greater resistance, utilising stress response pathways, mycotoxin degradation mechanisms and DNA repair (34).

The variation in the mycotoxin effects in our study may partly be owed to the differences in the structure of the plasma membrane between the species and even between the strains of the same species (18).

\section{CONCLUSION}

The sensitivity of Saccharomyces cerevisiae, S. uvarum, Candida utilis and Kluyveromyces marxianus yeast cells to mycotoxins varies depending on the ability of $\mathrm{AFB}_{1}$, OTA or ZEA to penetrate the cell membrane. The observed changes in the morphology, cell diameter and FTIR absorptions point to the mycotoxin binding to the cell membrane, particularly in C. utilis. There are indications of cell membrane denaturation, except for the S. uvarum exposed to OTA and ZEA. The effects of the mycotoxins on fermentation correspond to the detected sensitivity of yeasts. Our results also suggest that all studied yeast strains developed a specific adaptive response to mycotoxins, which might suggest that certain yeasts could be used to control mycotoxin concentrations in the production of fermented food and beverages.

\section{ACKNOWLEDGEMENTS}

This research was supported by the Council for Agricultural Research of the Croatian Ministry of Agriculture. We wish to thank Dado Čakalo for his helpful edits.

\section{REFERENCES}

1. Majara M, O'Connor-Cox ESC, Axcell BC. Trehalose - A stress protectant and stress indicator compound for yeast exposed to adverse conditions. J Am Soc Brew Chem. 1996;54(4):221-7.

2. Bleoanca I, Bahrim GE. Overview on brewing yeast stress factors. Rom Biotech Lett. 2013;18(5):8559-72.

3. Foszczyńska B, Dziuba E, Chmielewska J, Kawa-Rygielska J. Effect of DAS, ZEA and OTA mycotoxins on the fermentation activity of brewing yeast. EJPAU. 2008;11(1):Article no. 09.

4. Bauer EF, Pretorius LS. Yeast stress response and fermentation efficiency: How to survive the making of wine - $A$ review. S Afr J Enol Vitic. 2000;21:27-51.

5. Dziuba E, Foszczyńska B, Stempniewicz R. Effect of mycotoxins DAS, ZEA and OTA on the growth of brewing yeast. Pol J Food Nutr Sci. 2007;57(4A):123-9. 
6. Foszczyńska B, Dziuba E. Physiological status of brewing yeast during fermentation of worts contaminated with mycotoxins. P.1: T-2 and ZEA. Acta Sci Pol Biotechnol. 2007;6(1):3-12.

7. Foszczyńska B, Dziuba E. Physiological status of brewing yeast during fermentation of worts contaminated with mycotoxins. P.2: DAS and OTA. Acta Sci Pol Biotechnol. 2007;6(2):25-34.

8. Kłosowski G, Mikulski D, Grajewski J, Błajet-Kosicka A. The influence of raw material contamination with mycotoxins on alcoholic fermentation indicators. Bioresour Technol. 2010;101(9):3147-52.

https://doi.org/10.1016/j.biortech.2009.12.040

9. Štyriak I, Conková E, Kmec V, Böhm J, Razzazi E. The use of yeast for microbial degradation of some selected mycotoxins. Mycotoxin Res. 2001;17(Suppl. 1):24-7.

https://doi.org/10.1007/BF03036705

10. Bejaoui H, Mathieu F, Taillandier P, Lebrihi A. Ochratoxin A removal in synthetic and natural grape juices by selected oenological Saccharomyces strains. J Appl Microbiol. 2004;97(5):1038-44. https://doi.org/10.1111/j.1365-2672.2004.02385.x

11. Shetty PH, Jespersen L. Saccharomyces cerevisiae and lactic acid bacteria as potential mycotoxin decontaminating agents. Trends Food Sci Technol. 2006;17(2):48-55. https://doi.org/10.1016/j.tifs.2005.10.004

12. Shetty PH, Hald B, Jespersen L. Surface binding of aflatoxin $B_{1}$ by Saccharomyces cerevisiae strains with potential decontaminating abilities in indigenous fermented foods. Int J Food Microbiol. 2007;113(1):41-6. https://doi.org/10.1016/j.jjfoodmicro.2006.07.013

13. Patharajan S, Reddy KRN, Karthikeyan V, Spadaro D, Lore A, Gullino ML, Garibaldi A. Potential of yeast antagonists on in vitro biodegradation of ochratoxin A. Food Control. 2011;22(2):290-6. https://doi.org/10.1016/j.foodcont.2010.07.024

14. Reddy KRN, Farhana NI, Salleh B, Oliveira CAF. Microbiological control of mycotoxins: Present status and future concerns. In: Méndez-Vilas A, editor. Current research, technology and education topics in applied microbiology and microbial biotechnology. Microbiology book series, vol.2 (2). Badajoz, Spain: Formatex Research Center; 2010. pp. 1078-86.

15. Piotrowska M, Masek A. Saccharomyces cerevisiae cell wall components as tools for ochratoxin A decontamination. Toxins. 2015;7(4):1151-62. https://doi.org/10.3390/toxins7041151

16. Pfliegler WP, Pusztahelyi T, Pócsi I. Mycotoxins - Prevention and decontamination by yeasts. J Basic Microbiol. 2015;55(7):805-18. https://doi.org/10.1002/jobm.201400833

17. Kłosowski G, Mikulski D. The effect of raw material contamination with mycotoxins on the composition of alcoholic fermentation volatile by-products in raw spirits. Bioresour Technol. 2010;101(24):9723-7.

https://doi.org/10.1016/j.biortech.2010.07.085

18. Boeira LS, Bryce JH, Steward GG, Flannigan B. Inhibitory effect of Fusarium mycotoxins on growth of brewing yeasts. 1 Zearalenone and fumonisin B. . J Inst Brew. 1999;105(6):36675.

https://doi.org/10.1002/j.2050-0416.1999.tb00027.x

19. Boeira LS, Bryce JH, Stewart GG, Flannigan B. Inhibitory effect of Fusarium mycotoxins on growth of brewing yeast. 2. Deoxynivalenol and nivalenol. J Inst Brew. 1999;105(6):376-81. https://doi.org/10.1002/j.2050-0416.1999.tb00028.x

20. Boeira LS, Bryce JH, Stewart GG, Flannigan B. The effect of combinations of Fusarium mycotoxins (deoxynivalenol, zearalenone and fumonisin $B_{1}$ ) on growth of brewing yeasts. J Appl Microbiol. 2000;88(3):388-403. https://doi.org/10.1046/j.1365-2672.2000.00972.x

21. Reiss J. Influence of the mycotoxins aflatoxin $B_{1^{\prime}}$ rubratoxin $B$, patulin and diacetoxyscirpenol on the fermentation activity of baker's yeast. Mycopathol Mycol Appl. 1973;51(4):337-45. https://doi.org/10.1007/BF02057804

22. Reiss J. Influence of Fusarium and Myrothecium mycotoxins on dehydrogenase activity of Saccharomyces cerevisiae. Mycopathologia. 1983;81(3):187-9.

23. Opus, v. 5.0, Bruker, Leiderdorp, The Netherlands; 2002. Available from: https://www.bruker.com.

24. Lefebvre D, Gabriel V, Vayssier Y, Fontagné-Faucher C. Simultaneous HPLC determination of sugars, organic acids and ethanol in sourdough process. LWT - Food Sci Technol. 2002;35(5):407-14.

https://doi.org/10.1006/fstl.2001.0859

25. STATISTICA, v. 7.1, StatSoft, Inc, Tulsa, OK, USA; 2005. Available from: http://www.statsoft.com.

26. Engler KH, Coker RD, Evans IH. Uptake of aflatoxin $\mathrm{B}_{1}$ and T-2 toxin by two mycotoxin bioassay microorganisms: Kluyveromyces marxianus and Bacillus megaterium. Arch Microbiol. 2000;174(6):381-5. https://doi.org/10.1007/s002030000215

27. Boeira LS, Bryce JH, Stewart GG, Flannigan B. Influence of cultural conditions on sensitivity of brewing yeast growth to Fusarium mycotoxins zearalenone, deoxynivalenol and fumonisin $B_{1}$. Int Biodeterior Biodegradation. 2002;50(2):69-81. https://doi.org/10.1016/S0964-8305(02)00070-7

28. Joannis-Cassan C, Tozlovanu M, Hadjeba-Medjdoub K, Ballet N, Pfohl-Leszkowicz A. Binding of zearalenone, aflatoxin $B$, and ochratoxin $A$ by yeast-based products: A method for quantification of adsorption performance. J Food Prot. 2011;74(7):1175-85. https://doi.org/10.4315/0362-028X.JFP-11-023

29. Jouany JP, Yiannikouris A, Bertin G. The chemical bonds between mycotoxins and cell wall components of Saccha- 
romyces cerevisiae have been identified. Arch Zootech. 2005;8:26-50.

30. Turner JJ, Ewald JC, Skotheim JM. Cell size control in yeast. Curr Biol. 2012;22(9):R350-9.

https://doi.org/10.1016/j.cub.2012.02.041

31. Holubářová A, Müller P, Svoboda A. A response of yeast cells to heat stress: Cell viability and the stability of cytoskeletal structures. Scr Med (Brno). 2000;73(6):381-92.

32. Brauer MJ, Huttenhower C, Airoldi EM, Rosenstein R, Matese JC, Gresham D, et al. Coordination of growth rate, cell cycle, stress response, and metabolic activity in yeast. Mol Biol
Cell. 2008;19(1):352-67.

https://doi.org/10.1091/mbc.E07-08-0779

33. Hatab S, Yue T, Mohamad O. Removal of patulin from apple juice using inactivated lactic acid bacteria. J Appl Microbiol. 2012;112(5):892-9.

https://doi.org/10.1111/j.1365-2672.2012.05279.x

34. Ianiri G, Idnurm A, Wright SAl, Durán-Patrón R, Mannina L, Ferracane $R$, et al. Searching for genes responsible for patulin degradation in a biocontrol yeast provides insight into the basis for resistance to this mycotoxin. Appl Environ Microbiol. 2013;79(9):3101-15.

https://doi.org/10.1128/AEM.03851-12 